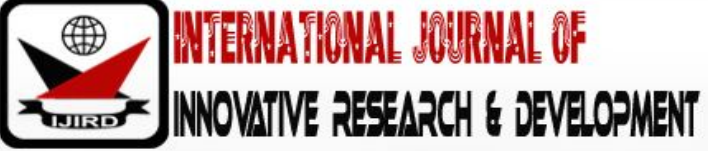

ISSN 2278 - 0211 (Online)

\section{Pre-Incarceration Career Aspirations and Educational Pursuit of Inmates in Abia State, Nigeria's Penitentiary}

\author{
Dr. Ogechi Roseline Obiozor \\ Lecturer, Department of Adult and Continuing Education, \\ Michael Okpara University of Agriculture, Nigeria \\ Ike Nwachukwu \\ Professor, Department of Agricultural Extension, \\ Michael Okpara University of Agriculture, Nigeria
}

\begin{abstract}
:
The study assessed the pre-incarceration career aspirations and educational pursuit of inmates in Abia State's penitentiary. Specifically, it described the socio-economic characteristics of the inmates, identified their livelihood activities before incarceration; ascertained career aspirations of the inmates after incarceration, and the educational opportunities available in the prisons. A simple random technique was used to draw 162 inmates from Umuahia, Aba and Arochukwu prisons, as sample size. Structured questionnaire was used for data collection. Data were analyzed using descriptive statistics; means and frequencies. The study found that Abia state prisons were dominated by males, young and singles with small number of females, both within the mean age of 27.7. Livelihood activities before incarceration of the inmates showed that the majority of them (51.9\%) were Artisan/ Craft workers, followed by Business men/women (38.9\%), Stealing (21.6\%), raping (10.5\%) while video coverage and editing recorded the lowest (6.8\%). For career aspiration after incarceration, the study showed that trading had $34.0 \%$ while artisan had $33.3 \%$. That was followed by vehicle driving (25.3\%), engineering (24.1\%), law $(20.4 \%)$, teaching $(21.6 \%)$, pastoring $(19.1 \%)$, and, farming $(17.9 \%)$. This showed a huge shift in their career aspirations before and after incarceration. It was found that there were educational programmes in the prison, from basic to university education. This enabled the inmates to acquire more education which influenced their new career aspirations. It was therefore recommended that the Government should fund these educational programmes adequately so that the prisons would be reformatory.
\end{abstract}

Keywords: Penitentiary, incarceration, inmates, career, educational

\section{Introduction}

The prison is where those who violate the laws of the land are kept. It serves as both a place of punishment and reformation. The idea is that every inmate should learn a skill before finishing his/ her term in prison so that such will be well integrated into the society when released from prison. With about 640.000 offenders released every year worldwide, prison education is the best rehabilitation tool for inmates and ex-convicts in their career aspirations, though availability and quality vary(Zoukis 2015). As a result of this, the Nigerian government has emphasized on remedial reforms and activities in prisons to improve the lives of the inmates. So, prison has become a correctional institution where inmates are provided with educational opportunities by law, to develop their self-worth, sense of responsibility, respect for peace and order, effective socialization and career maintenance during and after incarceration. According to Vacca (2004), enabling ex-convicts to successfully access higher education and put the education to good use through gainful employment is of great benefit to the whole society because uneducated ex-offenders have higher rates of recidivism. Vacca further explained that it costs more to re-incarcerate than to educate. At a base level, educated inmates become productive members of society which benefits overall. This enables them to learn life skills, pay taxes and provide for their families(Tietjen 2013).

Adult learning is the act of acquiring new knowledge, orientation, skills, aptitudes by individuals who have been seen by the society where they live as mature and responsible for their actions.Learning is knowledge oriented and lifelong based because individuals learn from cradle to grave (Obiozor and Obidiegwu 2013). As adults go through this process of change in behavior which involves acquisition of knowledge, values, norms, skills, they tend to have clearer perspective of life issues and rational thinking. Adult learning clearly connects with adult development and also seen as effective correctional education. Continued learning especially in the prison enriches the learner's skill, making him more employable and also better prepared for any business ventures of his own that he may wish to undertake on discharge. The personal benefits include a happier mental state, and increased confidence, as well as the potential for exciting opportunities to arise from continued learning. 
The reformation principle of prisons has given the inmates hope for future. Interestingly, the penitentiary has been redesigned to transform the life of the inmates with a view to correcting them.The major objective of Nigeriaprison service is reformation and rehabilitation of prisoners through a complex set of mechanism consisting of counseling, group work, casework sessions, recreational activities, religious services, adult and remedial education programmes. The reformation process does not only try to identify the causes of the inmates' anti-social behavior but also endeavors to set them on the road of reformation through induced self-rediscovery and eventual re-integration (Ihejieto 2014).

According to Iwuagwu as cited in the punch (2015), ensuring that prison inmates get skill acquisition while in prison is not just about empowering them. It will keep them off crime, improve their human dignity, help their socioeconomic integration and contribute to the country's Gross Domestic Product. Amidst success stories, a group of inmates at the Eastern New York Correctional Facility defeated the team of Harvard, the number two ranked University in the world, in a debate competition. This underscores the huge potential that prison facilities hold all over the world. Educational and vocational opportunities also help to reduce boredom and idleness and stress associated with incarceration. Keeping inmates constructively occupied is essential to the safety of correctional staff, inmates and the surrounding communities. These programmes are also designed to promote health, to reduce illness and related costs, and to increase the potential for post release involvement in health-related activities.

However, in the Nigeria prisons, Onyekachi (2016) discovered that inmates were willing and available to utilize opportunities but some factors hinder access to these opportunities. These include; congestion in Nigeria prisons which poses serious constraints to effective prison administration, inadequate funding of prisons by the Federal Government.In another study by Uche et al (2015), the educational programmes in the Nigerian prisons have not achieved much. It was discovered that the duration of service for the inmates did not make the inmates to be actively involved in rehabilitation programme.

\subsection{Statement of the Problem}

The educational and vocational opportunities provided in the prisons have the purpose ofremolding, encouraging and assisting inmates to live a good life on discharge. Ozoelom (2014) stated that industries are being revamped as industrial evolutions in Nigeria prisons. This is to meet current demand of our contemporary societies and subsequently take over the various distributions of goods in our market and world at large. On the contrary, recent studies discovered that, the educational programmes in the Nigeria prisons have not achieved much; more so, recidivism currently stands at $68 \%$. Out of every 1,000 individuals convicted in Nigeria, 680 will likely be back in the prison (Onyekachi 2016). While the Nigerian Government has provided educational and vocational studies in the prisons, there is a paucity of studies on the effectiveness of this programmes and how the inmates are responding to these facilities,hence, this study.

\subsection{Objectives of the Study}

The main objective of this study was to determine the pre-incarceration career aspiration and educational pursuit of inmates in Abia State Penitentiary. The specific objectives were to:

- Describe the socio-economic characteristics of the inmates

- Identify the livelihood activities of the inmates before incarceration

- Determine the career aspirations of the inmates after incarceration

- Ascertain the educational opportunities available in the prison

\section{Methodology}

This study was a descriptive survey. This research design was used to collect data from the inmates in order to determine the pre-incarceration career aspirations and educational pursuit of inmates in Abia State penitentiary. The population of the study comprised all the prison inmates in Abia State which were located in Arochukwu, Aba and Umuahia. A simple random sampling technique was adopted to select 54 prison inmates from each zone which made a total of 162 respondents that formed the sample size. The major instrument for data collection was structural questionnaire that required information from the respondents.

Except where the respondents are expected to tick within their range appropriately, all other items were structured on yes or no answers to be precise. Cronbach Coefficient Alpha was applied to determine the internal consistency of the instrument and the coefficient alpha values of $0.71,0.75,0.72$ and 0.76 were obtained respectively for the four sections and were considered adequate for the study. The researchers were helped by the prison education officers in administering and retrieving of the questionnaire which gave hundred percent retrieval.

Mean scores, frequencies and percentages were used in answering the research questions.

\section{Results and Discussion}

\subsection{Socio-Economic Characteristics of the Respondents}

Table 1 shows the socio-economic characteristics of the inmates in Abia State. The data show that $90 \%$ of the respondents were males, while their female counterparts had a low percentage, and the mean age was 27.7 years. Others results show that they were with Ordinary School Certificate (46.3\%); $71.0 \%$ were not married; almost all the respondents were Christians, with $50 \%$ being of the Pentecostal denomination.

The implications of these results are that males commit most of the crimes in our society today and are quite in large number in prisons especially in the study area. Having mean age of $27.7 \%$ shows that these are youths, able bodied, mostly single, who have attained good educational qualification. This tallied with the opinion of Kulu and Mannir (2018) 
that Nigerian prisons are dominated by male gender. On the area of religion, though the highest number of inmates belonged to the Pentecostal Christian group but it was also discovered that even Muslims, orthodox Christian and those who belonged to no religion also committed crimes. This showcases the insight from Ihejieto (2014) that the reformation process does not only identify the causes of the inmates' anti-social behavior but also endeavours to set them on the road of reformation through induced self-rediscovery irrespective of the background.

\subsection{Results}

\subsubsection{Socio-Economic Characteristics of the Inmates}

\begin{tabular}{|c|c|c|c|}
\hline Variable & Frequency $(n=162)$ & Percentages & Mear \\
\hline \multicolumn{4}{|c|}{ - } \\
\hline Male & 146 & 90.1 & \\
\hline Female & 16 & 9.9 & \\
\hline \multicolumn{4}{|l|}{ Age } \\
\hline $18-28$ & 100 & 61.7 & \\
\hline $29-38$ & 46 & 28.4 & \\
\hline $39-48$ & 16 & 9.9 & 27.7 \\
\hline \multicolumn{4}{|l|}{ Educational attainment } \\
\hline Below FSLC & 17 & 10.5 & \\
\hline FSLC & 51 & 31.5 & \\
\hline O Level & 75 & 46.3 & \\
\hline Degree & 18 & 11.1 & \\
\hline Masters & 1 & 0.6 & \\
\hline Ph.D & Nil & & \\
\hline \multicolumn{4}{|l|}{ Marital Status } \\
\hline Single & 115 & 71.0 & \\
\hline Married & 44 & 27.2 & \\
\hline Divorced & 1 & 0.6 & \\
\hline Widowed & 2 & 1.2 & \\
\hline \multicolumn{4}{|l|}{ Family size } \\
\hline None & 91 & 56.2 & \\
\hline $1-3$ & 36 & 22.2 & \\
\hline $4-6$ & 21 & 13.0 & \\
\hline $7-9$ & 12 & 7.4 & \\
\hline \multirow{2}{*}{\multicolumn{4}{|c|}{ Religion }} \\
\hline & & & \\
\hline Muslim & 3 & 1.9 & \\
\hline Orthodox Christian & 65 & 40.1 & \\
\hline Pentecostal Christian & 81 & 50.0 & \\
\hline No Religion & 13 & 8.0 & \\
\hline
\end{tabular}

Table 1: Distribution of the Respondents Based on the Socio Economic Characteristic Source: Field Survey Data 2018

\section{Livelihood Activities Before Incaceration}

Table 2 shows the distribution of inmates based on livelihood activities before incarceration in Abia State. The data show that Artisan/Craft work as means of livelihood had 51.9\%, while Business men and women were 38.9\%. This was followed by farming (29.6\%) driving (29.6\%), civil service (17.3\%), and other menial jobs, including stealing. From these results, it could be seen that majority of the respondents had livelihood activities which should ordinary prevent them from crimes. However, it is known that the lack of job is not the only reason why people commit crimes, and then, there are many reasons why people are jailed. 


\begin{tabular}{|ll|l|l|}
\hline S/N & Livelihood Activities (n=162) & Yes & No \\
\hline 1 & Civil Servant & $28(17.3)$ & $134(82.7)$ \\
2 & Business man/woman & $63(38.9)$ & $99(61.1)$ \\
3 & Artisan/Handiwork & $84(51.9)$ & $78(48.1)$ \\
4 & Computer Engineering & $31(19.1)$ & $131(80.9)$ \\
5 & Farming & $48(29.6)$ & $114(70.4)$ \\
6 & Photographing & $20(12.3)$ & $142(87.7)$ \\
7 & Nowork & $25(15.4)$ & $137(84.6)$ \\
8 & Video Coverage and Editing & $11(6.8)$ & $151(93.2)$ \\
9 & Driving & $48(29.6)$ & $114(70.4)$ \\
10 & Theft & $35(21.6)$ & $127(78.4)$ \\
11 & Raping & $17(10.5)$ & $145(89.5)$ \\
12 & Others & $26(16.0)$ & $136(84.0)$ \\
\hline
\end{tabular}

Table 2: Distribution of Inmates Based on Livelihood Activities before Incarceration Notes: (\%), Multiple Responses Recorded

\section{Career Aspiration after Incaceration}

Table 3 shows the career aspirations of the inmates after incarceration. The data indicated that trading had $34.0 \%$, while artisan had $33.3 \%$. That was followed by driving $(25.3 \%)$, engineering $(24.1 \%)$, law $(20.4 \%)$, teaching (21.6\%), pastoring (19.1\%), and farming (17.9\%). Medicine and Nursinghad 7.4\% and $6.8 \%$ respectively.

The results from this Table show a clear improvement on the career choices of the inmates. While there was increase in engaging in noble profession like engineering, law, medicine, farming; no respondent mentioned the ignoble profession of stealing and raping. The implication of this is that there must have been reformatory activities in the prisons. It also shows that the educational and vocational programmes were functional. It is worthy of note that a significant number of the respondents would like to be Ministers of God. It meant that the prison impacted positively on most of the inmates.

\begin{tabular}{|l|l|l|l|}
\hline $\mathbf{S} / \mathbf{N}$ & Career $(\mathbf{n}=\mathbf{1 6 2})$ & Yes & No \\
\hline 1 & Lawyer & $33(20.4)$ & $129(79.6)$ \\
2 & Engineer & $39(24.1)$ & $123(75.9)$ \\
3 & Doctor & $12(7.4)$ & $150(92.6)$ \\
4 & Nurse & $11(6.8)$ & $151(93.2)$ \\
5 & Teacher & $35(21.6)$ & $127(78.4)$ \\
6 & Artisan & $54(33.3)$ & $108(66.7)$ \\
7 & Pastor & $31(19.1)$ & $131(80.9)$ \\
8 & Photographer & $16(9.9)$ & $146(90.1)$ \\
9 & Farmer & $10(17.9)$ & $133(82.1)$ \\
10 & Imam & $55(34.0)$ & $152(93.8)$ \\
11 & Trading & $41(25.3)$ & $107(66.0)$ \\
12 & Driving & $30(18.5)$ & $121(74.7)$ \\
13 & Others & & $132(81.5)$ \\
\hline
\end{tabular}

Table 3: Distribution of Inmates Based on Career Aspiration after Incaceration Notes: (\%), Multiple Responses Recorded

\section{Educational Opportunities Available in the Prison}

Table 4 shows the educational opportunities available in the prison. It was discovered that Bible Training class had the highest percentage (85.8\%), followed by moral instruction (75.3\%). Others were; Adult and Remedial education (60.5\%), Basic Primary School (65.4\%) group team work programme (55.6 \%,) Open University (53.7\%), Agricultural skills (47.5\%), computer lessons (33.3\%), Islamic training class (29.0\%).

During the data collection and tour of the prisons, we were pleasantly surprised that these educational facilities were functional. There were computer laboratories, and the Open University had a center in Umuahia prison and many inmates were enrolled to pursuedifferent degree programmes. However, what they lacked in the prisons were adequate 
spaces and facilities for the programmes. The rooms were small for the computer labs and classrooms. They also lacked adequate funds to run the programmes effectively.

\begin{tabular}{|c|c|c|c|}
\hline $\mathbf{S} / \mathbf{N}$ & Educational Opportunities $(n=162)$ & Yes & No \\
\hline 1 & $\begin{array}{l}\text { Adult and Remedial education } \\
\text { programme, Jamb preparation, SSCE } \\
\text { preparation class }\end{array}$ & $98(60.5)$ & $64(39.5)$ \\
\hline 2 & Basic Primary School & $106(65.4)$ & $56(34.6)$ \\
\hline 3 & Computer lessons & $54(33.3)$ & $108(66.7)$ \\
\hline 4 & Open University & $87(53.7)$ & $75(46.3)$ \\
\hline 5 & Bible training class & $139(85.8)$ & $23(14.2)$ \\
\hline 6 & Islamic training class & $47(29.0)$ & $115(71.0)$ \\
\hline 7 & Moral instruction & $122(75.3)$ & $40(24.7)$ \\
\hline 8 & Agricultural Skills & $77(47.5)$ & $85(52.5)$ \\
\hline 9 & Group/team work programme & $90(55.6)$ & $72(44.4)$ \\
\hline 10 & Others & $6(3.7)$ & $156(96.3)$ \\
\hline
\end{tabular}

Table 4: Assessment of Available Educational Opportunities Available in the Prison Notes: (\%), Multiple Responses Recorded

\section{Conclusion and Recommendation}

The study concluded that males outnumbered their female counterparts in the prisons. The prison had positive impact on the career aspirations of the inmates, as many of them pursued noble professions while in the plenipotentiary, different from the bad profession they came into the prison with.

There were functional educational facilities provided in the prisons, such that one can pursue educational aspiration from the primary school to the university while serving terms in the prison. However, the facilities were not in conducive environment. Space was not adequate and funding of the educational facilities was a big challenge.

The study therefore recommended that since the inmates are willing and available to utilize educational opportunities, factors such as de-congestion, adequate funding and Technical training of the prison officials, should be emphasized to achieve the desired reformation policies.

\section{References}

i. Ihejieto, C.P. (2014). Effective and efficient prisons service and rehabilitation of inmates in Abia state of Nigeria. A study of some selected prisons. A dissertation presented in the department of sociology, Abia state University, Uturu.

ii. Kulu, H.A. \& Manir, A. (2018). Participation of prison inmates in vocational skills acquisition programmes for selfreliance and sustainable economic growth in Sokoto state, Nigeria. Review of European Studies, Vol. 10, No.2

iii. Obiozor, W.E. \& Obidiegwu U.J. (2013). Globalization of Adult Education. Theories and strategies for instructors. Awka: one street consulting limited.

iv. Onyekachi, J. (2016).Problems and prospects of administration of Nigeria Prisons. Need for proper rehabilitation of the inmates in Nigeria prisons. Journal of tourism and hospitality.

v. Ozoelom O.C. (2014). Industrial evolution in Nigeria prisons, Nigeria prison service.

vi. The Punch. Punch Nov. (2015) punch.com>without prison vocation. Retrieved on the 15th of April, 2018 from punch.com>without prison vocation.

vii. Tietjen, G. (2013). Exploring educational pathways: reintegration of the formerly incarcerated through the academy. Lincoln: Nebreska. http:/ / digitalcommons.unl.edu/ sociologydiss/ 24.

viii. Uche B.I., Uche A.O., Ezumah N.N., Ebue O.M., Okafor E.A. \& Ezegbe N.B. (2015). Effectiveness of rehabilitation programs in the Nigeria prisons: a study of perception of inmates in Enugu prison. Mediterranean Journal of Social Sciences Vol. 6(4).

ix. Vacca J. S. (2004). Educated prisoners are likely to return to prison.Journal of correctional education, Vol, 55, 297305.

x. Zoukis C (2015). The importance of effective correctional education, United States; Prison Education. 